\title{
KEJAHATAN KEKERASAN SEKSUAL (PERKOSAAN) TERHADAP ANAK DAMPAK DAN PENANGANANNYA DI WILAYAH HUKUM KABUPATEN CIANJUR
}

\author{
Hj. Mia Amalia \\ Wakil Rektor II dan sebagai Dosen Fakultas Hukum
}

\begin{abstract}
ABSTRAK
Maraknya pemberitaan mengenai kekerasan seksual terhadap anak cukup membuat masyarakat terkejut. Hal ini disebabkan kebanyakan anak yang menjadi korban kekerasan seksual enggan melapor. Kekerasan seksual terhadap anak akan berdampak panjang disamping berdampak pada masalah kesehatan di kemudian hari juga berkaitan dengan trauma yang berkepanjangan bahkan hingga dewasa. Bila tidak ditangani dengan serius kekerasan seksual terhadap anak dapat menimbulkan dampak sosial yang luas di masyarakat. Di dalam memberikan perlindungan terhadap anak perlu adanya pendekatan sistem yaitu meliputi sistem kesejahteraan sosial bagi anak-anak dan keluarga, sistem peradilan yang sesuai dengan standar internasional dan mekanisme untuk mendorong perilaku yang tepat dalam masyarakat.
\end{abstract}

Kata Kunci: Kekerasan Seksual, Anak, Dampak, Penanganan.

\section{ABSTRACT}

The rise of news about the sexual abuse of children is enough to make people shocked. This is due to most of the children who are victims of sexual violence are reluctant to report. Sexual abuse of children will go a long way in addition to result in health problems later in life is also associated with the trauma of prolonged even into adulthood. If not dealt with serious sexual abuse of children can cause social impact in the community. In providing protection for children need their systems approach that includes social welfare system for children and families, the judicial system in accordance with international standards and mechanisms to encourage appropriate behavior in society.

Keywords: Sexual Abuse, Child, Impact, Handling.

\section{PENDAHULUAN.}

\section{A. Latar Belakang Penelitian.}

Kasus kejahatan kekerasan seksual terhdapa anak merupakan salah satu kasus yang mengalami peningkatan secara signifikan belakangan ini. Tidak saja meningkatkan secara kuantitatif tapi juga secara kualitatif. Dari waktu ke waktu kejahatan kekerasan seksual terhadap anak jumlahnya tidak terbendung dan modus operandinya pun semakin tidak berprikemanusiaan. Dan yang lebih tragis lagi pelakunya adalah kebanyakan dari lingkungan keluarga atau lingkungan 
sekitar anak itu berada, antara lain di dalam rumahnya sendiri, sekolah, lingkungan sosial anak. ${ }^{1}$

Anak menjadi kelompok yang sangat rentan terhadap kejahatan kekerasan seksual Karen anakan selalu diposisikan sebagai sosok lemah atau yang tidak berdaya dan memiliki ketergantungan yang tinggi dengan orang-orang dewasa di sekitarnya. Hal inilah yang membuat anak tidak berdaya saat diancam untuk tidak memberitahukan apa yang dialaminya. Kemampuan pelaku menguasai korban baik dengan tipu daya amupun ancaman dan kekerasan menyebabkan kejahatan ini sulit dihindari. Dari seluruh kasus kekerasan seksual pada anak baru terungkap setelah peristiwa itu terjadi, dan tidak sedikit yang berdampak fatal. ${ }^{2}$

Secara umum pengertian kekerasan seksual pada anak adalah adalah suatu bentuk penyiksaan anak di mana orang dewasa atau remaja yang lebih tua menggunakan anak untuk rangsangan seksual. Bentuk pelecehan seksual anak termasuk meminta atau menekan seorang anak untuk melakukan aktivitas seksual (terlepas dari hasilnya), memberikan paparan yang tidak senonoh dari alat kelamin untuk anak, menampilkan pornografi untuk anak, melakukan hubungan seksual terhadap anak-anak, kontak fisik dengan alat kelamin anak (kecuali dalam konteks non-seksual tertentu seperti pemeriksaan medis), melihat alat kelamin anak tanpa kontak fisik (kecuali dalam konteks non-seksual seperti pemeriksaan medis), atau menggunakan anak untuk memproduksi pornografi anak. ${ }^{3}$

Kekerasan seksual pada anak baik perempuan maupun laki-laki tentu tidak boleh dibiarkan. Kekersan seksual pada anak adalah pelanggaran moral dan hukum, serta melukai secara fisik dan psikologis. Kekerasan seksual terhadap anak dapat dilakukan dalma bentuk sodomi, pemerkosaan, pencabulan serta incest.

Efek kekerasan seksual terhadap anak antara lain depresi, gangguan stres pascatrauma, kegelisahan, kecenderungan untuk menjadi korban lebih lanjut pada

1 Abintoro Prakoso, Pembaharuan Sistem Peradilan Pidana Anak, Yogyakarta, Laksbang Grafika, 2013, hlm. 37.

2 Maidin Gultom, Perlindungan Hukum terhadap Anak Dalam Sistem Peradilan Pidana Anak Di Indobesia, Rafika Aditama, Bandung, 2013, hlm. 49.

3 Abu Huraira, Kekerasan Terhadap Anak, Nuansa Press, Bandung, 2012, hlm. 89-90. 
masa dewasa, dan dan cedera fisik untuk anak di antara masalah lainnya. Pelecehan seksual oleh anggota keluarga adalah bentuk inses, dan dapat menghasilkan dampak yang lebih serius dan trauma psikologis jangka panjang, terutama dalam kasus inses orangtua.

Fenomena kekerasan seksual terhadap anak ini menunjukkan betapa dunia yang aman bagi anak semakins empit dan sulit ditemukan. Bagaimana tidak, dunia anak-anak yang seharusnya terisi dengan keceriaan, pembinaan dan penanaman kebaikan, harus berputar balik menjadi sebuah gambaran buram dan potret ketakutan karena anak sekarang telah menjadi subjek kejahatan kekerasan seksual.

Salah satu permasalahan yang menjadi fenomena kejahatan kekerasan seksual terhadap anak melanda di Kabupaten Cianjur, yang setiap hari terus mengalami peningkatan. Hingga bulan Oktober 2015, Pusat Pelayanan Terpadu Perlindungan Perempuan dan Anak (P2TP2A) Kabupaten Cianjur mencatat 110 kasus kekerasan seksual tersebut. Jumlah ini tinggi dibanding tahun 2014 yang hanya mencapai 61 kasus. Menurut Kabid Advokasi P2TP2A Kabupaten Cianjur, Lidya Indayani Umar, naiknya kasus tersebut melebihi kasus perdagangan manusia (Human Trafficking) dan kekerasan dalam rumah tangga (KDRT). Dua kasus terakhir sudah sangat jarang terjadi, dalam sebulan terjadi hanya satu atau dua kasus saja, Korban kekerasan seksual dalam kasus-kasus yang dilaporkan ke P2TPA adalah perempuan yang berada pada usia 4 sampai 17 tahun. Dan pelaku ialah orang-orang terdekat mereka, seperti paman, ayah, tetangga dan teman. ${ }^{4}$

Menanggapi kasus kekerasan seksual kepada anak di Kabupaten Cianjur yang semakin meningkat. Ada beberapa faktor meningkatnya kekerasan seksual terhadap anak salah satunya adalah banyaknya warga Cianjur yang memutuskan untuk menjadi tenaga kerja indonesia (TKI) di luar negeri, menjadi alasan utama lemahnya peran orangtua untuk melindungi anak-anak mereka.Penyebab kedua, tidak ada tempat hiburan yang bisa diakses oleh setiap pelaku kejahatan jenis ini. Mengingat, Cianjur sebagai kota santri. Sehingga, mereka mencari celah untuk

\footnotetext{
4 Ester Lima, Darurat Nasional, Eksploitasi Seksual Anak, 2013,http:/regional.kompasiana.com/2013/07/darurat-nasional-eksploitasi-seksual-anak579268.html. diakses pukul 20.30.
} 
melakukan kejahatan tersebut. Ini (kejahatan) sudah mengkhawatirkan, apalagi bagi orangtua yang memiliki anak perempuan. ${ }^{5}$

Maraknya kasus kekerasan seksual yang terjadi pada perempuan saat ini seperti yang ramai diperbincangkan disejumlah media sosial, cetak maupun elektronik. Mengingat pelaku kejahatan merupakan usia sekolah membuat sejumlah kalangan angkat bicara terhadap permasalahan itu. Forum Komunikasi Umat Beragama Kabupaten Cianjur mengatakan, pihaknya sangat prihatin terhadap peramasalahan tersebut. Pasalnya, permasalaahn itu bukanlah permasalahan yang biasa dan dalam hal ini semua pihak harus terlibat serta bertanggung jawab dalam menyelesaikan permasalahan itu. Ini menandakan saat ini akhlak anak remaja sudah rusak. Hal itu disebabkan karena terlalu banyaknya tayangan televisi yang tidak berbobot atau mengandung unsur pendidikan, misalkan banyak mengandung pornografi, seperti di film banyak mengandung adegan ciuman, pegangan tangan. Dalam permasalahan itu harus ada kerjasama semua pihak antara orang tua siswa, sekolah, dinas pendidikan, pemerintah daerah serta masyarakat. Sehingga tidak ada lagi kaum perempuan yang menjadi korban kekerasan seksual.

Perlu adanya pembinaan akhlak secara terus menerus melalui kegiatan keagamaan di sekolah. Selain itu, dalam hal ini juga perlu adanya pengawasan orang tua secara ketat di rumah. Jangan sampai dalam pada saat melakukan pengawasan tersebut orang tua lengah. Sementara itu, Sekretaris Dinas Pendidikan Kabupaten Cianjur, mengatakan, permasalahan kekerasan yang terjadi pada perempuan merupakan permasalahan sosial yang terjadi di kalangan anak remaja. Tak hanya itu, secara tidak langsung juga telah mencoreng nama baik dunia pendidikan. Maka dari itu untuk mengantisipasi hal tersebut agar tidak terjadi di Kabupaten Cianjur.

Dinas Pendidikan Kabupaten Cianjur akan terus memantau segala aktivitas siswa di sekolah melalui para pengawas ditiap-tiap daerah. Selain itu, akan melakukan kerjasama dengan pihak kepolisian dan ulama dalam hal pembinaan

5 Ibid. 
akhlak. Salah satunya upaya mengatasi hal tersebut dengan terus gencar melakukan suatu pembiasaan keagamaan ke tiap-tiap sekolah.

Kekerasan seksual di Kabupaten Cianjur mendominasi kasus kekerasan terhadap anak dalam kurun beberapa tahun terakhir. Korbannya rata-rata merupakan anak dari keluarga marjinal (kurang mampu). Project Officer Cianjur Save The Children, Dudy Hidajat, mengatakan bahwa fenomena kekerasan terhadap anak, salah satunya di Kabupaten Cianjur, trennya cenderung meningkat. Rata-rata anak menjadi korban, namun tak sedikit juga kasus yang menempatkan anak sebagai pelaku. Baik dari segi kualitas maupun kuantitas, fenomena kekerasan seksual terhadap anak ini seakan tidak akan pernah berhenti. Bentuk kekerasannya bervariasi seperti kekerasan fisik, psikis, seksual, penelantaran, eksploitasi, maupun perdagangan anak, baik itu untuk tujuan ekonomi maupun seksual. Bahkan tak sedikit kasus yang melibatkan pelakunya adalah orang asing yang menetap di Indonesia. ${ }^{6}$

Angka kejahatan semakin meningkat meski ancaman hukuman bagi pelaku begitu berat melebihi ancaman terhadap perampokan, yakni Pasal 81 Undang-undang nomor 35 tahun 2014, dengan hukuman palingsingkat 5 tahun kurungan dan paling lama 15 tahun.

Dengan adanya permasalah di atas, penulis merasa tertarik dengan mengambil tema dalam jurnal ini adalah "KEJAHATAN KEKERASAN SEKSUAL (PERKOSAAN) TERHADAP ANAK DAMPAK DAN PENANGANANNYA DI WILAYAH HUKUM KABUPATEN CIANJUR".

\section{B. Identifikasi Masalah.}

Berdasarkan latar belakang yang telah dipaparkan di atas, maka di dapat suatu permasalahan yaitu :

1. Dampak dari adanya kejahatan kekerasan seksual terhadap anak di kabupaten Cianjur?

6 Anonim (2014) Stop Kekerasan Pada Anak, 21 April 2014, diunduh dari http;??knkpos.com/stop-kekerasan-pada-anak/, akses pada 7 Mei 2014. 
2. Penanganan kejahatan kekerasan seksual terhadap anak oleh Pemerintah Kabupaten Cianjur?

\section{Tujuan Penelitian.}

Penelitian mengenai kejahatan kekerasan seksual (Perkosaan) terhadap anak dampak dan penanganannya di wilayah hukum Kabupaten Cianjur mempunyai tujuan umum dan tujuan khusus yaitu sebagai berikut :

1. Tujuan umum : untuk mengetahui pengaturan dan kebijakan dalam lapangan hukum pidana khususnya mengenai kekerasan seksual (Perkosaan) terhadap persoalan-persoalan hukum yang meliputi legitimasi hukum, arah perubahan tujuan hukum, penegakan hukum dan pengembangan teori, konsep, asas-asas, doktrin hukum pidana pada umumnya.

2. Tujuan khusus : Tujuan khsuus penelitian ini berkaitan dengan mendeskripsikan dan menganalisis secara mendalam tentang kejahatan kekerasan seksual (Perkosaan) dampak dan penanganannya di wilayah hukum Kabupaten Cianjur yang meliputi teori-teori, faktor penyebab, dampak dan upaya penanggulangannya karena terdapat berbagai macam dan ragamnya kejahatan kekerasan seksual yang semakin tidak terkendali, mengkhawatirkan kelangsungan hidup bangsa negara dan masyarakat di Kabupaten Cianjur.

\section{METODE PENELITIAN.}

Metode yang dilakukan adalah merupakan penelitian normatif . Dalam upaya pemecahan masalah maka pendekatan dilakukan secara konseptual, dengan studi dokumentasi terhadap peraturan perundang-undangan yang sedang berlaku di Indonesia. Pendekatan masalah dalam peneltiian ini bersifat konseptual yang bertujuan memberi gambaran struktur hukum secara vertikal.

Bahan hukum yang digunakan adalah bahan hukum primer dan sekunder. Bahan hukum primer adalah UUD 1945 dan KUHP , sedangkan bahan hukum sekunder berupa pandangan para sarjana dalam buku-buku literature maupun 
artikel yang menunjang pemahaman bahan hukum primer diabntu dengan informasi melalui internet.

\section{PEMBAHASAN.}

\section{A. Dampak Kejahatan Kekerasan Seksual Terhadap Anak di Kabupaten Cianjur.}

Perkosaan tidak dapat dipandang sebagai kejahatan yang hanya menjadi urusan privat (individu korban), namun harus dijadikan sebagai problem publik karena kejahatan ini jelas-jelas merupakan bentuk perilaku yang tidak bermoral dan keji yang selain melanggar Hak Asasi Manusia (HAM), juga mengakibatkan derita fisik, sosial maupun psikologis bagi kaum perempuan. Perkosaan dan penanganannya selama ini menjadi salah satu indikasi dan bukti lemahnya perlindungan (pengayom) hak asasi manusia, khsuusnya perempuan dari tindakan kekerasan seksual yang tergolong pada kekerasan terberat. ${ }^{7}$

Dari perspektif yuridis yang merujuk pada ketentuan KUHP tidak ditemukan definisi secara jelas mengenai kejahatan kekerasan akan tetapi hanya disebutkan dalam Pasal 89 "Membuat orang pingsan atau tidak berdaya disamakan dengan menggunakan kekerasan", dari rumusan pasal tersebut dapat dikatan bahwa kekerasan merupakan kejahatan yang dilakukan dan disertai dengan menggunakan kekuatan fisik yang berakibat pingsan atau tidak berdaya. Dengan berkembangnya jaman, pemahaman kekerasan dapat dilakukan dengan ancaman (psikologis) dan tindakan nyata (fisik). ${ }^{8}$

Komnas Perempuan mengidentifikasi kekerasan seksual memiliki 15 bentuk, yaitu: Perkosaan, intimidasi seksual termasuk ancaman atau percobaan perkosaan, pelecehan seksual, eksploitasi seksual, perdagangan perempuan untuk tujuan seksual, prostitusi paksa, perbudakan seksual, pemaksaan perkawinan, termasuk cerai gantung, pemaksaan kehamilan, pemaksaan aborsi, pemaksaan kontrasepsi dan sterilisasi, penyiksaan seksual, penghukuman tidak manusiawi

7 Sri Maslihah, Kekerasan Terhadap Anak model Transisional dan Dampak Jangka Panjang, Edukid, Jurnal Pendidikan Anak Usia Dini , 2006, hlm. 32-33.

8 E Barabara Bogorad, Sexsual Abuse Surviving The Paint, The American Agcademy Of Experts In Traumatic Stress Inc (online), 2008. 
dan bernuansa seksual/diskriminatif, praktik tradisi bernuansa seksual yang membahayakan atau mendiskriminasi perempuan, dan kontrol seksual, termasuk lewat aturan diskriminatif beralasan moralitas dan agama. ${ }^{9}$

Pengaturan mengenai kejahatan di Indonesia diatur dalam peraturan yang telah dikodifikasi dalam KUHP. Terdapat dua jenis tindak pidana perkosaan dalma KUHP yaitu :

a. Pasal 285 diatur mengenai tindka pidana perkosaan untuk bersetubuh.

b. Pasal 289 mengatur mengani tindak pidana perkosaan untuk berbuat cabul.

Dalam Pasal 285 KHUP tidak ditegaskan apa yang menjadi unsur kesalahan baik itu snegaja atau alpa. Namun dengan dicantumkannya unsur memaksa dalam rumusan pasalnya, maka jelas bahwa perkosaan merupakan perbuatan yang dilakukan dengans engaja. Dapat dikatakannya tindakan perkosaan apabila telah terjadi persetubuhan antara pelaku dan korban. Apabila tidak sampai terjadi persetubuhan maka perbuatan dimaksud dapat dikualifikasikan dengan tindak pidana percobaan perkosaan untuk bersetubuh (Pasal 285 Jo Pasal 53 KUHP) dan tindak perkosaan untuk berbuat cabul (Pasal 289 KUHP). ${ }^{10}$

Kemajuan ilmu dan teknologi perkembangan kependudukan dan struktur masyarakat serta perubahan nilai-nilai sosial dan budaya ikut mempengaruhi dan memberikan dampak yang terssendiri kepada motif, sifat, bentuk, frekuensi, intensitas, maupun modus operandi kejahatan kekerasan seksual. Banyak faktor secar langsung atau tidak langsung ikut memberi warna dan dampak tersendiri terhadap timbulnya kejahatan kekerasan seksual. ${ }^{11}$

Menurut Abdulsyani, terdapat dua sumber penyebab terjadinya tindakan kekerasan sumber pertama adalah faktor intern seperti sakit jiwa, daya emosional, rendahnya mental, anomi, umur, sex, kedudukan individu dalam masyarakat, pendidikan individu, masalah hiburan individu. Sedangkan faktor kedua adalah

9 Suradi, Problema dan Solusi Strategi Kekerasan Terhadap Anak, Informasi Kajian Permasalahan Sosial dan Usaha Kesejahteraan Sosial, Volume 18 No 02 Tahun 2013.

Ibid

11 Sri Maslihah. Op.Cit. 
faktor eksteren yaitu bersumber dari luar diri individu seperti ekonomi, agama, bacaan pornografi, film porno, narkotika, minuman keras. ${ }^{12}$

Menjadi korban kekerasan dan pelecehan seksual akan memberikan banyak dampak negatif yang dirasakan pada diri korban. Beberapa dampak yang paling sering dijumpai adalah:

1. Dampak Psikologis.

Dari hasil studi sebanyak 79\% korban kekerasan dan pelecehan seksual akan mengalami trauma yang mendalam, selain itu stres yang dialami korban dapat menganggu fungsi dan perkembangan otaknya.

2. Dampak Fisik.

Kekerasan dan Pelecehan seksual pada anak merupakan faktor utama penularan Penyakit Menular Seksual (PMS).

3. Dampak Cidera Tubuh.

Kekerasan dan pelecehan seksual pada anak dapat menyebabkan luka internal dan pendarahan. Pada kasus yang parah, kerusakan organ internal dapat terjadi. Dan dalam beberapa kasus dapat menyebabkan kematian. Hal ini dipengaruhi oleh umur korban dan tingkat kekuatan pelaku saat melakukan kejahatannya.

4. Dampak Sosial.

Korban kekerasan dan pelecehan seksual sering dikucilkan dalam kehidupan sosial, hal yang seharusnya kita hindari karena korban pastinya butuh motivasi dan dukungan moral untuk bangkit lagi menjalani kehidupannya. ${ }^{13}$

Berdasarkan informasi yang diterima oleh Komnas perlindungan anak, pada tahun 2013 kasus kekerasan dan pelecehan seksual pada anak di Indonesia semakin meningkat, 40\% diantaranya terjadi di lingkungan sekolah, 30\% di lingkungan keluarga, dan 30\% di lingkungan sosial. Jumlah kasusnya meliputi

12 Lukman Hakim Nainggolan, Bentuk-Bentuk Kekerasan Seksual Terhadap Anak di Bawah Umur, Jurnal Equality, Vol 13 No 1 Februari 2008.

13 Renata kristiani, Haruskah Anak Kita Menjadi Korban, Newletter Pulih, Volume 15 Tahun 2010, Yayasan Pulih, Jakarta, hlm. 4. 
sodomi sebanyak 52 kasus, perkosaan 280 kasus, pencabulan 182 kasus, dan incest (hubungan seks sedarah) 21 kasus. ${ }^{14}$

Anak yang mendapat kekerasan seksual dampak jangka pendeknya akan mengalami mimpi-mimpi buruk, ketakutan yang berlebihan pada orang lain, dan konsentrasi menurun yang akhirnya akan berdampak pada kesehatan. Untuk jangka panjangnya, ketika dewasa nanti dia akan mengalami fobia pada hubungan seks atau bahkan yang parahnya lagi dia akan terbiasa dengan kekerasan sebelum melakukan hubungan seksual. Bisa juga setelah menjadi dewasa, anak tesebut akan mengikuti apa yang dilakukan kepadanya semasa kecilnya.

Untuk itu solusi yang terbaik, dari penangan medis janganlah hanya sebatas kesembuhan saja, tetapi juga pada psikologinya dan dilakukan dengan secara berkala atau intensif. Namun yang membuat miris, sebagian besar pelaku kekerasan seksual pada anak itu masih berkeliaran bebas karena tidak adanya pengaduan. Ini tentunya sangat kita sayangkan karena bisa jadi pelaku justru melakukan perbuatan yang sama pada anak lainnya karena tidak ada efek jera.

Menurut Data pengaduan yang diterima Komisi Penanggulangan Anak Indonesia (KPAID) Sumut selama tahun 2012 tercatat kekerasan seksual terhadap anak mencapai 46 kasus atau sekitar $27.4 \%$ dari 171 pengaduan yang diterima. Ketua Pokja Pengaduan dan Fasilitasi Pelayanan KPAID Sumut, Muslim Harahap mengatakan bahwa tingginya angka kekerasan seksual yang dialami anak disebabkan oleh beberapa faktor, di antaranya kurang maksimalnya peran penyelenggara negara dalam memberikan perkembangan hak terhadap anak. Bahkan, dukungan masyarakat saat ini masih katagori seremonial dan kurang adanya aksi. ${ }^{15}$

Pelecehan seksual yang terjadi pada masa anak-anak adalah aktifitas seksual yang terjadi pada anak-anak karena dibujuk atau dipaksa oleh orang yang lebih tua tanpa disadari atau difahami oleh anak. Bentuknya berupa meraba, hubungan badan, atau bentuk eksploitasi yang lain. Pelecehan seksual tersebut membawa dampak fisik dan psikologis. Anak menjadi gelisah, pendiam,

14 Op. Cit, Anonim, Stop Kekerasan Pada Anak, 2014.

15 Ibid. 
mengucilkan diri, merasakan sensasi seksual yang berkepanjangan, melakukan masturbasi, ketakutan-ketakutan infantil, bahkan hingga menjadi seorang pedofilia, homoseksual atau pelacur di masa dewasanya nanti. Anak korban pelecehan seksual, ada yang mampu keluar dari penderitaan tersebut (resilience), sehingga mereka mampu menjadi orang dewasa yang bermental sehat, peka terhadap lingkungan sosial. ${ }^{16}$

Dampak fisik dan psikologis yang dialami subjek seperti: gelisah, susah tidur, merasakan sensasi seksual, terdorong untuk melakukan masturbasi, mengalami stres yang menyebabkan terlambat datangnya haid, protektif dalam bergaul dengan lawan jenis, regresi atau infantil, sehingga ada ketakutan untuk menikah, takut akan gelap dan kesepian, ingin melebihi laki-laki dan sangat selektif dalam memilih laki-laki sebagai pasangan hidup. Namun subjek mampu mengatasi beberapa dampak pelecehan seksual tersebut dan tidak menjadi orang yang menyimpang dari norma masyarakat, atau dengan kata lain mampu resilient dengan didukung faktor protektif resilience, berupa: pertama, faktor instrinsik, yaitu: kekuatan diri yang solid, keoptimisan, percaya diri, konsep diri yang jelas, kontrol diri yang bagus dan sensitifitas terhadap lingkungan sosial; kedua, faktor ekstrinsik, yaitu: penanaman falsafah hidup dari orang tua dan kerabat, pertemanan yang solid dan positif, aktifitas sekolah yang menyenangkan dan teladan dari seorang guru, serta komunitas yang responsif terhadap subjek. ${ }^{17}$

Namun dengan lemahnya koordinasi penyelenggara negara terkait pentingnya perlindungan anak, juga menjadi penyebab tingginya kekerasan seksual terhadap anak. Sejauh ini, masih banyak pemberitaan kekerasan seksual terhadap anak di Kabupaten Cianjur. Beberapa kasus bahkan berhenti di tengah jalan karena adanya perdamaian. Kondisi ini tentu saja tidak memberikan efek jera bagi pelaku sehingga tidak takut untuk melakukan kekerasan seksual, terutama bagi anak.

16 Dinar Wahyuni, Kejahatan Seksual Anak dan Gerakan Nasional Anti Kejahatan Seksual Terhadap Anak, Info Singkat Kesejahteraan Sosial, Vol VI, No 12/II/P3DI/Juni/2014.

17 Weber, Mark Reese, Smith, Dana M, Outcomes Of Child Sexsual Victimization, dalam Jurnal of Internasional Violence (Online), 26 (9), 1899-1905, 2010. 


\section{B. Penanganan Mengatasi Kejahatan Kekerasan Seksual di Kabupaten Cianjur.}

Pada umumnya, upaya perlindungan anak dapat dibagi menjadi perlindungan langsung dan tidak langsung, dan perlindungan yuridis dan nonyuridis. Upaya-upaya perlindungan secara langsung di antaranya meliputi: pengadaan sesuatu agar anak terlindungi dan diselamatkan dari sesuatu yang membahayakannya, pencegahan dari segala sesuatu yang dapat merugikan atau mengorbankan anak, pengawasan, penjagaan terhadap gangguan dari dalam dirinya atau dari luar dirinya, pembinaan (mental, fisik, sosial), pemasyarakatan pendidikan formal dan informal, pengasuhan (asah, asih, asuh), pengganjaran (reward), pengaturan dalam peraturan perundang-undangan. ${ }^{18}$

Sedangkan, upaya perlindungan tidak langsung antara lain meliputi: pencegahan orang lain merugikan, mengorbankan kepentingan anak melalui suatu peraturan perundang-undangan, peningkatan pengertian yang tepat mengenai manusia anak serta hak dan kewajiban, penyuluhan mengenai pembinaan anak dan keluarga, pengadaan sesuatu yang menguntungkan anak, pembinaan (mental, fisik dan sosial) para partisipan selain anak yang bersangkutan dalam pelaksanaan perlindungan anak, penindakan mereka yang menghalangi usaha perlindungan anak. $^{19}$

Kedua upaya perlindungan di atas sekilas nampak sama dalam hal bentuk upaya perlindungannya. Perbedaan antara keduanya terletak pada objek dari perlindungan itu sendiri. Objek dalam upaya perlindungan langsung tentunya adalah anak secara langsung. Sedangkan upaya perlindungan tidak langsung, lebih pada para partisipan yang berkaitan dan berkepentingan terhadap perlindungan anak, yaitu orang tua, petugas dan pembina. Demi menimbulkan hasil yang optimal, seyogyanya upaya perlindungan ini ditempuh dari dua jalur, yaitu dari jalur pembinaan para partisipan yang berkepentingan dalam perlindungan anak, kemudian selanjutnya pembinaan anak secara langsung oleh para partisipan

18 Wismayanti, Farida Yanuar, Perlindungan Anak Berbasis Komunikasi di Wilayah Perbatas, Penelitian Aksi di Desa Entikong, Kec Entikong Kab Sanggau, pro Kalimantan Barat, Sosiokonsepsia Vol. 17, No 01, jakarta, 2012.

19 Ibid. 
tersebut. Upaya-upaya ini lebih merupakan upaya yang integral, karena bagaimana mungkin pelaksanaan perlindungan terhadap anak dapat berhasil, apabila para partisipan yang terkait seperti orang tua, para petugas dan pembina, tidak terlebih dahulu dibina dan dibimbing serta diberikan pemahaman mengenai cara melindungi anak dengan baik. ${ }^{20}$

Ditinjau dari sifat perlindungannya, perlindungan anak juga dapat dibedakan dari menjadi: perlindungan yang bersifat yuridis, meliputi perlindungan dalam bidang hukum perdata dan dalam hukum pidana; perlindungan yang bersifat non-yuridis, meliputi perlindungan di bidang sosial, bidang kesehatan dan bidang pendidikan. Perlindungan yang bersifat yuridis atau yang lebih dikenal dengan perlindungan hukum. Menurut Arief hal tersebut merupakan upaya perlindungan hukum terhadap berbagai kebebasan dan hak asasi anak (fundamental rights and freedoms of children) serta berbagai kepentingan yang berhubungan dengan kesejahteraan anak. ${ }^{21}$

Perlindungan hukum dalam bidang keperdataan, terakomodir dalam ketentuan dalam hukum perdata yang mengatur mengenai anak seperti, (1) Kedudukan anak sah dan hukum waris; (2) pengakuan dan pengesahan anak di luar kawin; (3) kewajiban orang tua terhadap anak; (4) sebelum dewasa anak dan perwalian.

Dalam hukum pidana, perlindungan anak selain diatur dalam Pasal 45, 46, dan 47 KUHP (telah dicabut dengan diundangkannya Undang-undang Nomor 11 Tahun 2012 tentang Sistem Peradilan Pidana Anak). Kemudian, terdapat juga beberapa pasal yang secara langsung atau tidak langsung berkaitan dengan perlindungan anak, yaitu antara lain Pasal 278, Pasal 283, Pasal 287, Pasal 290, Pasal 297, Pasal 301, Pasal 305, Pasal 308, Pasal 341 dan Pasal 356 KUHP.

Selanjutnya, dalam Undang-undang Nomor 23 Tahun 2002 Jo UndnagUndnag Nomor 35 Tahun 2014 tentang Perlindungan anak yang pada prinsipnya mengatur mengenai perlindungan hak-hak anak. Dalam Undang-undang Nomor 4

20 Sari A.P, Penyebab Kekerasan Seksual Terhadap Anak dan Hubungan Pelaku Dengan Korban, diunduh tanggal 27 Juli 2009 dari http://kompas.com/index.php/read/xml/2009/01/28/.

21 Eko Prasetyo dan Suparman Marzuki, Pelecehan Seksual, Fakultas Hukum Universitas Islam Indonesia, Yogyakarta, 1995, hlm. 5. 
tahun 1979, tentang Kesejahteraan Anak, pada prinsipnya diatur mengenai upayaupaya untuk mencapai kesejahteraan anak. Dan, yang terakhir Undang-undang Nomor 11 Tahun 2012 tentang Sistem Peradilan Pidana Anak, yang pada prinsipnya mengatur mengenai perlindungan terhadap anak sebagai pelaku tindak pidana dalam konteks peradilan anak.

Implementasi perlindungan hukum bagi anak sebagai korban ternyata belum maksimal sebagaimana yang diberikan oleh undang-undang. Walaupun belum maksimal, namun ada beberapa bentuk perlindungan hukum yang sudah diberikan kepada anak sebagai korban sesuai Undang-Undang No. 23 Tahun 2002 Pasal 64 ayat (3), bahwa anak sebagai korban mendapatkan (a) rehabilitasi baik dalam lembaga maupun luar lembaga, (b) upaya perlindungan dan pemberitaan identitas melalui media massa untuk menghindari labelisasi, (c) pemberian jaminan keselamatan bagi saksi korban dan saksi ahli baik fisik, mental, maupun sosial, dan (d) pemberian aksebilitas untuk mendapatkan informasi mengenai perkembangan perkara. ${ }^{22}$

Selain itu, hak anak sebagai korban yang menderita secara fisik perlu mendapatkan restitusi maupun kompensasi atas akibat penderitaan yang dialaminya. Sebagaimana terkandung dalam Deklarasi Prinsip-prinsip Dasar Keadilan Bagi Para Korban Kejahatan dan Penyalahgunaan Kekuasaan (Resolusi Majelis Umum PBB No. 40/34 tertanggal 29 November 1985). Deklarasi tersebut mengandung ketentuan-ketentuan sebagai berikut:

a. Para korban berhak untuk mendapatkan penggantian segera atas kerugian yang mereka derita.

b. Mereka harus diberitahu tentang hak mereka untuk mendapat ganti rugi.

c. Para pelaku atau pihak ketiga harus memberi restitusi yang adil bagi para korban, keluarga, dan tanggungjawab mereka. Penggantian demikian harus mencakup pengembalian hak milik atau pembayaran atas derita atau kerugian yang dialami, penggantian atas biaya yang dikeluarkan sebagai

22 J.E Sahetay, Kejahatan Kekerasan Suatu Pendekatan Interdispliner, Sinar Wijaya, Surabaya, 2008, hlm. 49. 
akibat viktimisasi tersebut, dan penyediaan pelayanan serta pemulihan hak-hak.

d. Bilamana kompensasi tidak sepenuhnya didapat dari pelaku atas sumbersumber lainnya, negara harus berusaha menyediakan kompensasi keuangan.

e. Para korban harus mendapat dukungan dan bantuan material, pengobatan, psikologis dan sosial yang diperlukan. ${ }^{23}$

Beberapa cara menghindari kekerasan fisik dan pelecehan seksual pada anak adalah :

1. Ajarkan keterbukaan. Ajarkan anak untuk tidak menyimpan rahasia dengan menstimulasi kebiasaan bertanya dan meminta si kecil bercerita kegiatan sehari-hari saat ia senang, sedih, takut dan gembira.

2. Hindari asesoris nama. Jangan kenakan kalung, gelang atau pakaian yang bertuliskan nama anak anda jika terpaksa anak harus jauh dari orang tua. Hal ini untuk menghindari orang asingatau oknum yang berniat jahat atau penculik yang menyebutkan nama seolah sudah mengenal si kecil dengan baik.

3. Mulailah mengajarkan "sex education" sejak dini di rumah. Ajarkan bagaimana menjaga kebersihan organ intim dan keamanan dari sentuhan orang asing selain anggota keluarga yang dikenalnya. Jika ada yang memegangnya ajarkan untuk berteriak dan lari.

4. Tidak mempercayai orang asing. Dalam budaya kita memang diajarkan ramah dan sopan, namun kondisi saat ini orang tua dituntut untuk pandaipandai menyampaikan kepada anak bagaimana sebaiknya bersikap kepada orang asing. ${ }^{24}$

Saat ini seperti yang sering kita dengar di berbagai media bahwa anakanak rentan menjadi sasaran pelecehan seksual selain faktor karakteristik kepribadian pelaku pelecehan, karakter personal yang dimiliki korban sedikit banyak berpengaruh seperti penampilan fisik, dimana saat ini pertumbuhan anak-

23 Abdul Wahid dan Muhammad Irfan, Perlindungan Terhadap Korban Kekerasan Seksual Advokasi Atas Hak Asasi Perempuan, PT Refika Aditama, Bandung, 2011, hlm. 94.

24 Darwan Prinst, Hukum Anak Indonesia, Citra Aditya Bakti, Bandung, 1997, hlm. 39. 
anak lebih cepat karena pengaruh hormon dan gizi. Selain itu perilaku anak yang mudah terbujuk dan dekat dengan orang asing sangat rentan dengan pelecahan seksual. Saat ini upaya untuk mengatasi kasus pelecehan seksual anak secara hukum telah ada Undang-Undang yang mengaturnya secara jelas. Yang masih membutuhkan perhatian adalah upaya pencegahannya. Upaya pencegahan harus dilakukan secara komprehensif, artinya tidak bisa dilakukan hanya satu pihak saja (orang tua dan keluarga) melainkan harus terintegrasi dengan pemerintah, sekolah serta tenaga professional yang memiliki konsentrasi terhadap pertumbuhan dan perkembangan anak. Jadi sebaiknya orang tua perlu memahami bahwa tindak kekerasan yang dialami oleh anak-anak sebenarnya bisa diatasijika ditangani dengan benar. Namun sebaliknya sudah dipastikan seandainya tidak ditangani, apalagi kekerasan itu dialami oleh anak itu terjadi di lingkungan rumah sendiri dalam jangka waktu yang lama dan dilakukan oleh orang tuanya. Bisa kita bayangkan beberapa tahun ke depan kita akan mendapatkan generasi yang memiliki gangguan psikologi akibat traumatik masa kecil. ${ }^{25}$

Upaya mengantisipasi berbagai kasus kekerasan anak Kabupaten Cianjur terus dilakukan. Salah satunya pengguliran Program Pengasuhan Anak Berbasis Keluarga. Di Kabupaten Cianjur program tersebut baru akan dilaksanakan di 6 desa di 3 kecamatan. Upaya kita adalah dengan melakukan program perlindungan dan pencegahan. Sebagai pilot project, di Kabupaten Cianjur dilaksanakan di Desa Cidadap dan Desa Sukajadi di Kecamatan Campaka, kemudian di Desa Cibinonghilir dan Desa Ciharashas di Kecamatan Cilaku, serta di Desa Sukamaju dan Kelurahan Sayang di Kecamatan Cianjur. Pemilihan lokasi yang dijadikan sebagai pilot projek itu itu didasari faktor geografis dan sosiologis. Artinya, Kecamatan Cianjur mewakili karakter wilayah perkotaan, Kecamatan Cilaku mewakili karakter wilayah semi perkotaan, dan Kecamatan Campaka mewakili karakter wilayah perkampungan sehingga terbentuk adanya suatu kampong dengan sebutan Kampung Ramah Anak (KRA). ${ }^{26}$

25 Ibid, hlm. 40-41.

26 Op.Cit, Ester Lima. 
Berbagai program perlindungan dan pengasuhan anak yang digulirkan ini ke depan bisa lebih dikembangkan dan diperluas ke wilayah kecamatan dan desa lainnya, untuk memastikan anak-anak dan keluarga memiliki akses kepada layanan sosial dasar, pendidikan, kesehatan dasar, dan perlindungan. Kemudian meningkatkan pemahaman pemangku kepentingan di tingkat kabupaten tentang pentingnya pencegahan keterpisahan anak dari keluarga. Menggali potensi dan tantangan yang dihadapi masyarakat di tingkat kabupaten dalam upaya perlindungan anak serta meningkatkan komitmen pemangku kepentingan di daerah dalam bentuk rencana aksi bersama, untuk mengatasi permasalahan kekerasan terhadap anak butuh kerja sama lintas sektoral. Sebab tidak hanya berbicara konteks perlindungan saja tapi juga sudah masuk dalam ranah hukum. Makanya, dalam kegiatan kami ini dilibatkan juga unsur dari kepolisian kejaksaan, Pusat Pelayanan Terpadu Pemberdayaan Perempuan dan Anak (P2TP2A) dan masyarakat dalam mengatasi maraknya kejahatan kekerasan seksual khususnya di Kabupaten Cianjur.

\section{PENUTUP.}

\section{A. Kesimpulan.}

Dampak dari kejahatan kekerasan seksual terhadap anak adalah : dampak psikologis,dampak fisik, dampak cidera tubuh, dampak sosial, korban kekerasan dan pelecehan seksual sering dikucilkan dalam kehidupan sosial,

Penanganan dalam kejahatan kekerasan seksual di Kabupaten Cianjur adalah Upaya-upaya perlindungan secara langsung di antaranya meliputi: pengadaan sesuatu agar anak terlindungi dan diselamatkan dari sesuatu yang membahayakannya, pencegahan dari segala sesuatu yang dapat merugikan atau mengorbankan anak, pengawasan, penjagaan terhadap gangguan dari dalam dirinya atau dari luar dirinya, pembinaan (mental, fisik, sosial), pemasyarakatan pendidikan formal dan informal, pengasuhan (asah, asih, asuh), pengganjaran (reward), pengaturan dalam peraturan perundang-undangan.

Sedangkan, upaya perlindungan tidak langsung antara lain meliputi: pencegahan orang lain merugikan, mengorbankan kepentingan anak melalui suatu 
peraturan perundang-undangan, peningkatan pengertian yang tepat mengenai manusia anak serta hak dan kewajiban, penyuluhan mengenai pembinaan anak dan keluarga, pengadaan sesuatu yang menguntungkan anak, pembinaan (mental, fisik dan sosial) para partisipan selain anak yang bersangkutan dalam pelaksanaan perlindungan anak, adanya pembinaan akhlak secara terus menerus melalui kegiatan keagamaan di sekolah ataupun di lingkungan masyarakat. Di kabupaten Cianjur digalakan adanya Kampung Ramah Anak (KRA).

\section{B. Saran.}

Terjadinya kasus perkosaan di Indonesia yang cenderung mengalami peningkatan, diharapkan agar pemerintah Indonesia memperbaharui produk perundang-undangan mengenai kejahatan seksual khususnya perkosaan itu dengan memperhatikan dan mengoptimalkan sanksi pidana yang bersifat lebih memberatkan agar timbul efek jera. Disamping itu masyarakat diharapkan lebih meningkatkan kewaspadaan terhadap perkembangan jaman dan teknologi. Selain itu pendidikan moral dan agama tetap menjadi prioritas, dengan memegang teguh nilai Pancasila. Untuk memaksimalkan upaya penanggulangan diharapkan partisipasi masyarakat dan konsistensi dari aparat penegak hukum. 


\section{DAFTAR PUSTAKA}

\section{A. Buku.}

Abdul Wahid dan Muhammad Irfan, Perlindungan Terhadap Korban Kekerasan Seksual Advokasi Atas Hak Asasi Perempuan, PT Refika Aditama, Bandung, 2011.

Abu Huraira, Kekerasan Terhadap Anak, Nuansa Press, Bandung, 2012.

Abintoro Prakoso, Pembaharuan Sistem Peradilan Pidana Anak, Yogyakarta, Laksbang Grafika, 2013.

Darwan Prinst, Hukum Anak Indonesia, Citra Aditya Bakti, Bandung, 1997.

J.E Sahetapy, Kejahatan Kekerasan Suatu Pendekatan Interdispliner, Sinar Wijaya, Surabaya, 2008.

Maidin Gultom, Perlindungan Hukum terhadap Anak Dalam Sistem Peradilan Pidana Anak Di Indonesia, Rafika Aditama, Bandung, 2013.

\section{B. Peraturan Perundang-undangan.}

Undang-Undang Dasar Negara Republik Indonesia 1945.

Kitab Undang-Undang Hukum Pidana.

Undang-Undang Nomor 23 Tahun 2002 Jo Undang-Undang Nomor 35 Tahun 2014 tentang Perlindungan Anak.

\section{Jurnal, Artikel, Makalah, Majalah, Koran, Internet, dan Lain-lain.}

Anonim (2014) Stop Kekerasan Pada Anak, 21 April 2014, diunduh dari http;//knkpos.com/stop-kekerasan-pada-anak/, akses pada 7 Mei 2014.

Dinar Wahyuni, Kejahatan Seksual Anak dan Gerakan Nasional Anti Kejahatan Seksual Terhadap Anak, Info Singkat Kesejahteraan Sosial, Vol VI, No 12/II/P3DI/Juni/2014.

Ester Lima, Darurat Nasional, Eksploitasi Seksual Anak 2013,http:/regional.kompasiana.com/2013/07/darurat-nasional-eksploitasiseksual-anak-579268.html.diakses pukul 20.30

E. Barabara Bogorad, Sexsual Abuse Surviving The Paint, The American Agcademy Of Experts In Traumatic Stress Inc (online), 2008 
Eko Prasetyo dan Suparman Marzuki, Pelecehan Seksual, Fakultas Hukum Universitas Islam Indonesia, Yogyakarta, 1995,

Lukman Hakim Nainggolan, Bentuk-Bentuk Kekerasan Seksual Terhadap Anak di Bawah Umur, Jurnal Equality, Vol 13 No 1 Februari 2008.

Renata kristiani, Haruskah Anak Kita Menjadi Korban, Newletter Pulih, Volume 15 Tahun 2010, Yayasan Pulih, Jakarta

Sari A.P, Penyebab Kekerasan Seksual Terhadap Anak dan Hubungan Pelaku Dengan Korban, diunduh tanggal 27 Juli 2009 dari http://kompas.com/index.php/read/xml/2009/01/28/.

Sri Maslihah, Kekerasan Terhadap Anak Model Transisional dan Dampak Jangka Panjang, Edukid, Jurnal Pendidikan Anak Usia Dini I, 2006.

Suradi, Problema dan Solusi Strategi Kekerasan Terhadap Anak, Informasi Kajian Permasalahan Sosial dan Usaha Kesejahteraan Sosial, Volume 18 No 02 Tahun 2013.

Wismayanti, Farida Yanuar, Perlindungan Anak Berbasis Komunikasi di Wilayah Perbatas, Penelitian Aksi di Desa Entikong, Kec Entikong Kab Sanggau, propinsi Kalimantan Barat, Sosiokonsepsia Vo 17, No 01, Jakarta, 2012.

Weber, Mark Reese, Smith, Dana M, Outcomes Of Child Sexsual Victimization, dalam Jurnal Of Internasional Violence (Online), 26 (9), 1899-1905, 2010 